\title{
Resonance and/as Responsibility (How are We to Hear this Sounding?)
}

\author{
GERALDine FinN
}

\section{Preface}

This text was composed for oral presentation: written by ear to be (read as) heard. It stages an experiment ("expérience") with sound, and, as a written text, with the sight of sound on/off the page in order to at once solicit and perform the relationship between resonance and responsibility it seeks to explicate and expose. It begins therefore with a listening exercise consisting of the first 33 seconds of a popular song, which is not identified in the text in order to preserve the integrity of the experience (experiment) upon which the success of the paper depends. It is important therefore that you read the text aloud and listen to the accompanying sound recording only as and when instructed to do so, letting the rhythm and sonority of the first and subsequent listening examples, and the spacing of the words on the page, set the pace and tone of your own-resonant and response-able-reading. The sound recording is not an optional extra: it is not included as an example you can listen to at any time but is absolutely integral to the com-position (the "sens," i.e., the meaning and direction) of the written text. So please do not cheat! Read the text aloud and listen to the sound recording only as and when instructed to do so at sections 1, 7, and 11. Source material and scholarly references are provided in the endnotes, which should not be consulted until after your first uninterrupted reading of the paper. Thank you! 


\section{Resonance and/as Responsibility (How are We to Hear this Sounding?)}

1. Please listen [click here]

2. How are we to hear

this sounding

of the knell ${ }^{1}$

giving a sign

of the giving

of signs ${ }^{2}$

without benefit

of clergy ${ }^{3}$

\section{Let us stay}

with the resonances

of this first hearing

in order to get closer

to this essence

of the event ${ }^{4}$

entendre

entre

comme laisser

résonner

plus que

raissoner

understanding

hearing (entendre)

by resonance

rather than

by reason 
in order to

be more

response-able

\section{A response-ability}

or a decision

cannot be

founded

or justified

by any knowledge

as such

without a leap

between two

discontinuous

and radically

heterogenous

orders 5

silence

and

sound

rupture

$e(s) t$

retournement

such unpredictability

is precisely

what constitutes

the condition

for ethical engagement

and undecidability

as to if and how

to respond 
is the condition

for making a

responsible decision ${ }^{6}$

5. Let us not therefore

abandon this

first hearing

let us listen

from further away

in order to try

to be more

responsible

for our reason

as well as

for our heritage

and to try to

attune ourselves

to them

in a more

responsible

manner $^{7}$

\section{How then}

are we

to hear

this sounding

of the knell

which speaks

in the mode

of calling ${ }^{8}$

giving a sign

of the giving

of signs 
let's listen

again

in order to

try to be

more response-able

to its call

7. Please listen [click here]

\section{Everything is summoned}

from an intonation

and even earlier still

from what gives

its tone to the tone

a rhythm ${ }^{9}$

listening

we surmise

that not musical meaning

but human breathing

brought music

into the world ${ }^{10}$

in - halation

ex - halation

in - spiration

ex - spiration

re - spiration

the $\operatorname{arche}$

is always

a return 
everything

begins

by sending

back $^{11}$

rhythm

resonance

reverberation

music says

we

directly

regardless

of intention ${ }^{12}$

no man

is an island

entire of itself

every man

is a piece

of the continent

of the main ${ }^{13}$

at once unique

and in relation ${ }^{14}$

always already

in vibration

with an other

therefore

never send

to know

for whom

the bell tolls

it tolls

for thee ${ }^{15}$ 


\section{It calls}

$$
\begin{aligned}
& \text { to you } \\
& \text { and me } \\
& \text { to come } \\
& \text { à venir }
\end{aligned}
$$

come listen

come hear

here

hear

the call

of the other

is a call to come

à-venir

to the future

to come

and that happens

only in multiple voices ${ }^{16}$

undecidable

between

one

and

other

an inheritance

is never

gathered together

is never

one

with itself

its presumed unity

if there is one

can consist only

in the injunction 
to reaffirm

the injunction itself-

it always says

choose and decide

from among

what you inherit-

can only be one

by dividing itself

tearing

it self

a part

dif-fering

de-ferring

it-self

by speaking

at the same time

several times

and in

several voices $^{17}$

10. I do not

write about

these voices

I try to let them

take over

and keep

speech

through me

I try

to let them

speak 
the music

of voices

if there is any

I do not sign it

I cannot

precisely

have it

at my disposal

or in my control

if there is

any music

first of all

I listen to it

it is the experience itself

of impossible appropriation

the most joyous

and the most tragic

so let's listen

let's $\operatorname{listen}^{18}$

11. Please listen [click here, play Track 1 (purchase required)]

\section{Listening we are}

the ideal

mother

mother as

(an) idea(l)

attending to

the baby's cry 
alert to

its puling inscriptions

and

we are

the baby

listening to

the mother

for signs

of affection

and attention

for reciprocity

for world ${ }^{19}$

undecidable

between one

and other

between call

and response

separation from

and attachment

to the

mother

mama -

don't go

daddy -

come home

the voice

(of the)

music 
the music

(of the)

voice

cuts

both

ways

as authority

over the other

and as exposure

to the other ${ }^{20}$

a present

(présence)

constituted as

a between

symbolic gesture

and

primal scream

neither one

and other

rupture e(s)t retournement

séparation e(s)t rencontre

résonance e(s)t réponse

invocation

reciprocation

solicitation

the zwischen

reconstituted

in each fresh

meeting

and therefore

always novel 


always
calling
for a
fresh
response
one that
follows
not
by logic
but by
affinity

affect
and
résonance

\title{
13. Listening we surmise
}

\author{
that not \\ musical \\ meaning \\ but \\ human \\ breathing \\ brought music \\ into the world \\ in - halation \\ ex - halation \\ in - spiration \\ ex - spiration \\ re - spiration \\ the rhythm tone \\ of flesh and blood \\ and breath and bone
}




existence
hangs
on a push
of the lungs
which is at
the same time
an in - vocation
of the other
testimony (to)
of response
ability
of (to) approach
to (from)
the other
entre deux
la voix
'inscrit
resonance
and/as
response
dans la
rupture
ombilicale
says we
directly
e(s)t
cloture


(ability)

14. Mother

$$
\begin{aligned}
& \text { you - me } \\
& \text { I - you } \\
& \text { I- you } \\
& \text { you - me } \\
& \text { I- you } \\
& \text { father } \\
& \text { you - me } \\
& \text { I- you } \\
& \text { I- you } \\
& \text { you - me } \\
& \text { I- you } \\
& \text { children } \\
& \text { you - I } \\
& \text { I- I } \\
& \text { I- you }
\end{aligned}
$$

\section{This is not a game}

through which

mastery

is acquired

trajectory

not entity

seems to make the self

Freud's grandchild keeps the self going

through

the repetition 
of throwing the cotton reel out to an extreme

and hauling

it back ${ }^{25}$

fort $-d a$

gone - away

here - to stay

[all my troubles

seem so far away

oh I believe

in yesterday]

rupture

$e(s) t$

retournement

ouverture

répetition

écart

qui fonde

le discours

du sujet ${ }^{26}$

16. Music re-turns us

to the

primal scene

of loss

and

resolution

re - calls

re - members

re - peats

re - plays 
re - presents

re - pairs

the sonorous

unseen

in between

of becoming

one self

and as (for)

an other

as resonance

and response

(ability)

to the call

of the (m)other

a presence

constituted

as a between

music comes

and goes

music comes

to pass

music comes

as always

already passed

the moment

it is produced ${ }^{27}$

fort-da

it comes from the other and it is addressed

to the other 
it begins from the other and it goes back

to the other ${ }^{28}$

double

entendre

entre

raison e(s)t résonance

silence and sound

one and other

\section{We must stay}

within the difficulty

of this passage $e^{29}$

undecidable

between

what is

and

what is

not

to be

or not

to be

imaginary

real

symbolic

one

and

other

the lalalangue

of the mother tongue $^{30}$ 


sonorous
unseen
and the discourse
of the father
neither one
and other
nor
therefore
avoid
the order of
the disorder
produced
within it
here
there
scripted
or scored
hear
where
le son
leçon
tu son
the sound
of sound
on the
threshold
of sens $(\mathrm{e})$


18. Ajouis-sens $(\mathbf{e})^{32}$

of résonance

that requires

a different kind

of listening

corps-à-corps

double

entendre

entre

limbs lungs

lips larynx

teeth tongues

throat

belly

chest

and a corresponding

suspension of concepts

of categories and rules

of reason and right

to rid ourselves

of the habit

of always

hearing

what we

already

understand $^{33}$

to undergo

the experience

of sound 
without the

mythology of

a system $^{34}$

to give sound

a chance

son chance

sens chance

chance son

chanson

to give sound

the time

it needs

to speak

19. A kin-aesthetic ethic

of resonance and

as response ability

of affect

and attention

to the sonorous

presemantic

libidinal

materiality

maternality

of $\operatorname{sens}(\mathrm{e})^{35}$

the

sense of

becoming

the

becoming of

sense 


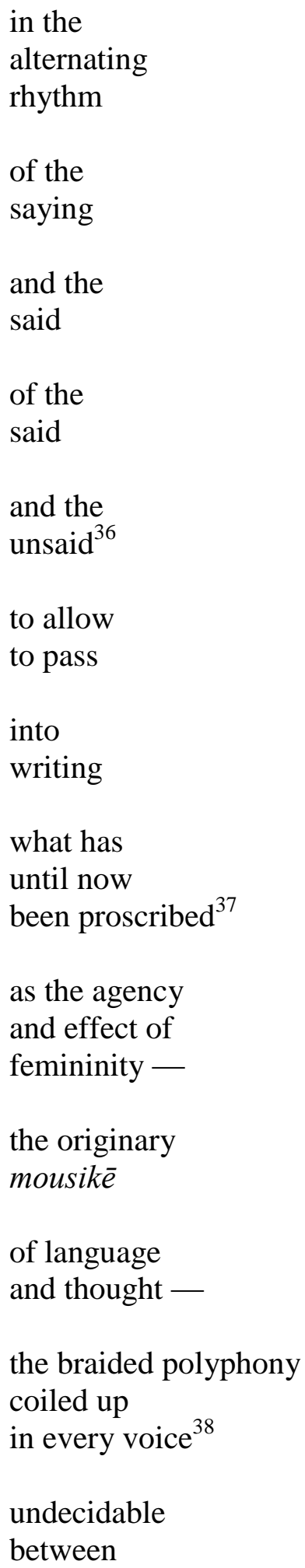


rhythm and tone

of flesh and blood

and breath and bone

the very song

that since Plato

metaphysics has

sought to repress 39

the history

the mystery

and the now ${ }^{40}$

resonance and

response-ability

corps-à-corps

a presence (present)

constituted as

a between

20. This is not a game

through which

mastery

is acquired

writing it

at first

is difficult

putting the

mind on it

takes the

ear off it ${ }^{41}$

it is the experience

itself of impossible

appropriation 


the most joyous
and the most
tragic
response-ability
without
finality
without
end
so let's listen
yes
let's
listen

\section{Notes}

1 “How are we to hear this.” Para-cited from Jacques Derrida, Rogues, 136.

2 “Giving a sign ... signs.” Para-cited from Emmanuel Lévinas, “God and Philosophy,” 184.

3 "Without ... clergy." Para-cited from Frank O'Hara, "New Directions in Music: Morton Feldman," 215.

4 “Let us ... event.” Para-cited from Jacques Derrida, Rogues, 135.

5 “A responsibility ... orders.” Para-cited from Jacques Derrida, Rogues, 145.

6 "Such unpredictability ...decision." Para-cited from Amit Pinchevski, By Way of Interruption, 10.

7 “Let us not ... manner.” Para-cited from Jacques Derrida, Rogues, 136.

8 “Speaks in the mode of calling." Para-cited from Martin Heidegger, "Language,” 199.

9 "Everything ... rhythm." Para-cited from Jacques Derrida, Monolingualism of the Other, 48. 
10 "Listening ... world." Para-cited from Morton Feldman, Give My Regards to Eighth Street, $61-2$.

11 “Everything ... back.” Para-cited from Jacques Derrida, Rogues, 108.

12 “Music ... intention.” Para-cited from Theodor Adorno, Aesthetic Theory, 167.

13 "No man ... main." Para-cited from John Donne, "Devotions Upon Emergent Occasions." Meditation XVII, 1674. The Oxford Book of Quotations, 190.

${ }^{14}$ For "uniqueness and relation" with reference to voice see Adriana Cavarero, For More Than One Voice, pp 16, 17, 198 and passim.

15 "Never send ... thee." Para-cited from John Donne, "Devotions Upon Emergent Occasions." Meditation XVII, 1964. The Oxford Book of Quotations, 190.

16 “The call ... voices.” Para-cited from Jacques Derrida, "From Psyche,” 343.

17 “An inheritance ... voices.” Para-cited from Jacques Derrida, Specters of Marx, 16.

18 "I do not ... listen." Para-cited from Jacques Derrida, "Passages-From Traumatism to Promise," 394-5.

19 “Listening ... world.” Para-cited from Wayne Kostenbaum, The Queen's Throat, 32-3.

20 "The voice ... other." Para-cited from Mladen Dolar, A Voice and Nothing More, 80.

21 "The zwischen ... response." Para-cited from Emmanuel Lévinas, "Martin Buber and the Theory of Knowledge," 65.

22 "One that ... affinity." Para-cited from Morton Feldman, Give My Regards to Eighth Street, 74.

23 “Existence ... other." Para-cited from Adriana Cavarero, For More Than One Voice, 169.

24 “La voix ... clôture.” Para-cited from Denis Vasse, L'Ombilic et La Voix, 16-17.

25 “This is not ... back." Para-cited from Marion Hobson, Jacques Derrida. Opening Lines, 166.

26 “Ouverture ... sujet.” Para-cited from Denis Vasse, L'Ombilic et Le Voix, 95.

27 "The first obvious quality of the voice is that it fades away the moment it is produced. Verba volent, scripta manent." Mladen Dolar, A Voice and Nothing More, 59. 
28 "It comes ... the other." Para-cited from Juan-David Nasio, Five Lessons on the Psychoanalytic Theory of Jacques Lacan, 135.

29 "We must ... passage." Para-cited from Jacques Derrida, "Différance," Margins of Philosophy, 22.

30 "Lalangue is something that one sucks, it is the maternal part of language that undergoes jouissance. Lalangue remains intimately linked to the body, and is thus eminently charged with meaning, full of meaning," Juan-David Nasio, Five Lessons on the Psychoanalytic Theory of Jacques Lacan, 5.

31 "Nor ... within it." Para-cited from Jacques Derrida, "Différance,” Margins of Philosophy, 4.

32 "Lacan coined the neologism jouis-sense, enjoyment-in-meaning-the moment at which the singing voice cuts loose from its anchoring in meaning and accelerates into a consuming selfenjoyment," Slavoj Žižek, “I Hear You With My Eyes,” 103-4.

33 “To rid ... understand.” Para-cited from Martin Heidegger, “The Nature of Language,” 58.

34 “Without ... system.” Para-cited from Morton Feldman, Give My Regards to Eighth Street, 80.

35 “Sonorous ... sens(e).” Para-cited from Adriana Cavarero, For More Than One Voice, 102.

36 “Alternating ... unsaid.” Para-cited from Emmanuel Lévinas, "God and Philosophy,” 186.

37 “To allow ... proscribed.” Para-cited from Adriana Cavarero, For More Than One Voice, 142.

38 “The braided ... voice.” Para-cited from Jacques Derrida, "Voice II.” Points, 162.

39 “The very ... repress.” Para-cited from Adriana Cavarero, For More Than One Voice, 142.

40 "The history ... now." Para-cited from William Parker, cited by Daniel Fischlin and Ajay Heble, The Other Side of Nowhere: Jazz, Improvisation and Communities in Dialogue, 4.

41 “Writing ... off it.” Para-cited from John Cage, “Lecture on Nothing,” 116. 


\section{Works Cited}

Adorno, Theodor. Aesthetic Theory. Ed. Gretel Adorno and Rolf Tiedermann. Trans. Robert Hullot-Kentor. Minneapolis: Minnesota University Press, 1997.

Cage, John. "Lecture on Nothing." Silence. Middletown: Wesleyan University Press, 1979. 109127.

Cavarero, Adriana. For More Than One Voice. Toward a Philosophy of Vocal Expression. Trans. Paul A. Kottman. Stanford: Stanford University Press, 2005.

Derrida, Jacques. "From Psyche." Acts of Literature. Ed. Derek Attridge. London: Routledge, 1992. 252-309.

- Monolingualism of the Other; Or, The Prosthesis of Origin. Trans. Patrick Mensah. Stanford: Stanford University Press, 1998.

—. "Passages_From Traumatism to Promise." Points ... Interviews, 1974 - 1994. Trans. Peggy Kamuf and others. Stanford: Stanford University Press, 1995. 372-295.

- Rogues. Two Essays on Reason. Trans. Pascale-Anne Brault and Michael Naas. Stanford: Stanford University Press, 2005.

—. Specters of Marx. Trans. Peggy Kamuf. New York: Routledge, 1994.

—. "Voice II." Points ... Interviews, 1974 - 1994. Trans. Peggy Kamuf and others. Stanford: Stanford University Press, 1995. 156-170.

Dolar, Mladen. A Voice and Nothing More. Cambridge: MIT Press, 2006.

Feldman, Morton. Give My Regards to Eighth Street. Collected Writings of Morton Feldman. Ed. B. H. Friedman. Cambridge: Exact Change, 2000.

Fischlin, Daniel and Heble, Ajay, eds. The Other Side of Nowhere: Jazz, Improvisation and Communities in Dialogue. Middletown: Wesleyan University Press, 2004.

Heidegger, Martin. "Language." Poetry, Language, Thought. Trans. Albert Hofstadter. New York: Harper and Row, 1971. 87-210.

—. "The Nature of Language." On The Way To Language. Trans. Peter D. Hertz. New York: Harper and Row, 1971. 57-108.

Hobson, Marion. Jacques Derrida. Opening Lines. London: Routledge, 1998. 
Kostenbaum, Wayne. The Queen's Throat. Opera, Homosexuality, and the Mystery of Desire. New York: Poseidon Press, 1993.

Lennon, John. 'Mother', John Lennon/Plastic Ono Band, originally recorded at Abbey Road studios, Autumn 1970. CD recording released by EMI, 2000.

Lévinas, Emmanuel. "God and Philosophy." The Levinas Reader. Ed. Sean Hand. Oxford: Blackwell, 1989. 166-189.

-. "Martin Buber. The Theory of Knowledge. The Levinas Reader. Ed. Sean Hand. Oxford: Blackwell, 1989. 59-74.

Nasio, Juan-David. Five Lessons on the Psychoanalytic Theory of Jacques Lacan. Trans. David Pettigrew and François Raffoul. Albany: SUNY Press, 1998.

O'Hara, Frank. "New Directions in Music: Morton Feldman." Morton Feldman Give My Regards to Eighth Street. Cambridge: Exact Change, 2000. 211-217.

The Oxford Book of Quotations. Third Edition. Oxford: Oxford University Press, 1980.

Pinchevski, Amit. By Way of Interruption. Levinas and the Ethics of Communication. Pittsburgh: Duquesne University Press, 2005.

Vasse, Denis. L'Ombilic et La Voix. Deux Enfants en Analyse. Paris: Editions du Seuil, 1974.

Žižek, Slovoj. "I Hear You With My Eyes.” Eds. Renata Salecl and Slavoj Žižek. Gaze and Voice as Love Objects. Durham: Duke University Press, 1996. 90-126. 